Supporting Information

\title{
Reactive Transport Modeling of Trichloroethene Treatment with Declining Reactivity of Iron
}

Sung-Wook Jeen ${ }^{1}$, K. Ulrich Mayer ${ }^{2}$, Robert W. Gillham ${ }^{1 *}$, and David W. Blowes ${ }^{1}$

${ }^{1}$ Department of Earth Sciences, University of Waterloo, Waterloo, Ontario, Canada N2L 3G1

${ }^{2}$ Department of Earth and Ocean Sciences, University of British Columbia, Vancouver, British Columbia, Canada V6T 1Z4

*Corresponding author tel: (519)888-4658; fax: (519)746-1829; e-mail: rwgillha@sciborg.uwaterloo.ca

Pages (including the cover page): 13

Contents: Five tables (S1-S5)

Five figures (S1-S5)

Prepared for Environmental Science \& Technology

December 5, 2006 
Table S1. Complexation reactions and equilibrium constants ${ }^{\mathrm{a}}$.

\begin{tabular}{llllr}
\hline Reaction & & & & Log K \\
\hline$(1)$ & $\mathrm{OH}^{-}$ & $\Leftrightarrow$ & $\mathrm{H}_{2} \mathrm{O}-\mathrm{H}^{+}$ & -13.998 \\
$(2)$ & $\mathrm{CaOH}^{+}$ & $\Leftrightarrow$ & $\mathrm{Ca}^{2+}+\mathrm{H}_{2} \mathrm{O}-\mathrm{H}^{+}$ & -12.780 \\
$(3)$ & $\mathrm{CaHCO}_{3}{ }^{+}$ & $\Leftrightarrow$ & $\mathrm{Ca}^{2+}+\mathrm{CO}_{3}{ }^{2-}+\mathrm{H}^{+}$ & 11.440 \\
$(4)$ & $\mathrm{CaCO}_{3}(\mathrm{aq})$ & $\Leftrightarrow$ & $\mathrm{Ca}^{2+}+\mathrm{CO}_{3}{ }^{2-}$ & 3.220 \\
$(5)$ & $\mathrm{FeOH}^{+}$ & $\Leftrightarrow$ & $\mathrm{Fe}^{2+}+\mathrm{H}_{2} \mathrm{O}-\mathrm{H}^{+}$ & -9.500 \\
$(6)$ & $\mathrm{Fe}(\mathrm{OH})_{2}(\mathrm{aq})$ & $\Leftrightarrow$ & $\mathrm{Fe}^{2+}+2 \mathrm{H}_{2} \mathrm{O}-2 \mathrm{H}^{+}$ & -20.570 \\
$(7)$ & $\mathrm{Fe}(\mathrm{OH})_{3}{ }^{-}$ & $\Leftrightarrow$ & $\mathrm{Fe}^{2+}+3 \mathrm{H}_{2} \mathrm{O}-3 \mathrm{H}^{+}$ & -31.000 \\
$(8)$ & $\mathrm{FeHCO}{ }^{+}$ & $\Leftrightarrow$ & $\mathrm{Fe}^{2+}+\mathrm{CO}_{3}{ }^{2-}+\mathrm{H}^{+}$ & 12.330 \\
$(9)$ & $\mathrm{FeCO}_{3}(\mathrm{aq})$ & $\Leftrightarrow$ & $\mathrm{Fe}^{2+}+\mathrm{CO}_{3}{ }^{2-}$ & 4.380 \\
$(10)$ & $\mathrm{FeCl}^{+}$ & $\Leftrightarrow$ & $\mathrm{Fe}^{2+}+\mathrm{Cl}^{+}$ & 0.140 \\
$(11)$ & $\mathrm{HCO}_{3}{ }^{-}$ & $\Leftrightarrow$ & $\mathrm{H}^{+}+\mathrm{CO}_{3}{ }^{2-}$ & 10.330 \\
$(12)$ & $\mathrm{H}_{2} \mathrm{CO}_{3}$ (aq) & $\Leftrightarrow$ & $2 \mathrm{H}^{+}+\mathrm{CO}_{3}{ }^{2-}$ & 16.681
\end{tabular}

\footnotetext{
${ }^{\mathrm{a}}$ The equilibrium constants were taken from the database of MINTEQA2 (1) and WATEQ4F (2).
} 
Table S2. Reaction stoichiometries of reduction-corrosion reactions.

\begin{tabular}{ll}
\hline Reaction & Stoichiometry \\
\hline TCE degradation & $\mathrm{Fe}^{0}(\mathrm{~s})+0.3448 \mathrm{C}_{2} \mathrm{HCl}_{3}+\mathrm{H}^{+} \rightarrow \mathrm{Fe}^{2+}+0.0172 \mathrm{C}_{2} \mathrm{H}_{2} \mathrm{Cl}_{2}+0.3276 \mathrm{C}_{2} \mathrm{H}_{4}+\mathrm{Cl}^{-}$ \\
Iron corrosion & $\mathrm{Fe}^{0}(\mathrm{~s})+2 \mathrm{H}_{2} \mathrm{O} \rightarrow \mathrm{Fe}^{2+}+\mathrm{H}_{2}(\mathrm{aq})+2 \mathrm{OH}^{-}$ \\
\hline
\end{tabular}


Table S3. Reaction rate constants and the initial reactive surface area of the iron.

\begin{tabular}{|c|c|c|c|c|}
\hline \multirow[t]{2}{*}{ Parameter } & \multicolumn{4}{|l|}{ Column } \\
\hline & $\begin{array}{l}\text { A } \\
\text { (D.I. } \mathrm{H}_{2} \mathrm{O}+10 \\
\text { mgL }^{-1} \text { TCE) }\end{array}$ & $\begin{array}{l}\mathrm{B} \\
\left(100 \mathrm{mgL}^{-1}\right. \\
\mathrm{CaCO}_{3}+10 \\
\left.\mathrm{mgL}^{-1} \mathrm{TCE}\right)\end{array}$ & $\begin{array}{l}\mathrm{C} \\
\left(100 \mathrm{mgL}^{-1}\right. \\
\mathrm{CaCO}_{3}+10 \\
\mathrm{mgL}^{-1} \mathrm{TCE}, \\
\left.\text { coarse }^{\mathrm{a}} \text { iron }\right)\end{array}$ & $\begin{array}{l}\mathrm{D} \\
\left(500 \mathrm{mgL}^{-1}\right. \\
\mathrm{CaCO}_{3}+10 \\
\left.\mathrm{mgL}^{-1} \mathrm{TCE}\right)\end{array}$ \\
\hline $\begin{array}{l}\log k_{\mathrm{SA}-\mathrm{TCE}-\mathrm{Fe}^{\mathrm{o}}} \mathrm{b} \\
\left(\mathrm{mol} \mathrm{m}^{-2} \operatorname{iron~s}^{-1}\right)\end{array}$ & -11.15 & -10.95 & -10.95 & -10.95 \\
\hline $\begin{array}{l}K_{1 / 2}{ }^{\mathrm{c}} \\
\left(\mathrm{mol} \mathrm{L}^{-1} \mathrm{H}_{2} \mathrm{O}\right)\end{array}$ & $1.83 \times 10^{-5}$ & $1.83 \times 10^{-5}$ & $1.83 \times 10^{-5}$ & $1.83 \times 10^{-5}$ \\
\hline $\log k_{\mathrm{SA}-\mathrm{H}_{2} \mathrm{O}-\mathrm{Fe}^{0}} \mathrm{~d}$ & -10.88 & -10.60 & -10.70 & -9.90 \\
\hline$\left(\mathrm{mol} \mathrm{m} \mathrm{m}^{-2}\right.$ iron s$\left.{ }^{-1}\right)$ & $(-10.88)$ & $(-10.41)$ & $(-10.67)$ & $(-10.06)$ \\
\hline $\begin{array}{l}\text { Initial reactive surface area } \\
\left(\mathrm{m}^{2} \text { iron } \mathrm{L}^{-1} \text { bulk) }\right.\end{array}$ & $8.37 \times 10^{3}$ & $8.37 \times 10^{3}$ & $6.80 \times 10^{3}$ & $8.37 \times 10^{3}$ \\
\hline
\end{tabular}

${ }^{\mathrm{a}}$ Grain size is $0.30-2.38 \mathrm{~mm}$, and is $0.17-1.41 \mathrm{~mm}$ in the other columns.

${ }^{\mathrm{b}}$ Calibrated to the earliest TCE profiles.

${ }^{\mathrm{c}}$ Half-saturation constant.

${ }^{\mathrm{d}}$ Based on the maximum corrosion rates (in parentheses) calculated from the laboratory-measured rates of gas generation at early times. The rates were further adjusted to reproduce the best simulation results.

${ }^{\mathrm{e}}$ Measured using the BET analyses. 
Table S4. Mineral dissolution-precipitation reactions and equilibrium constants.

\begin{tabular}{|c|c|c|c|}
\hline Reaction & & & $\log K$ \\
\hline $\mathrm{CaCO}_{3}(\mathrm{~s})$ (aragonite) & $\Leftrightarrow$ & $\mathrm{Ca}^{2+}+\mathrm{CO}_{3}^{2-}$ & $8.360^{\mathrm{a}}$ \\
\hline $\mathrm{Fe}_{2}(\mathrm{OH})_{2} \mathrm{CO}_{3}(\mathrm{~s})$ & $\Leftrightarrow$ & $2 \mathrm{Fe}^{2+}+\mathrm{CO}_{3}{ }^{2-}+2 \mathrm{H}_{2} \mathrm{O}-2 \mathrm{H}^{+}$ & $0.075^{b}$ \\
\hline $\mathrm{Fe}(\mathrm{OH})_{2}(\mathrm{am})$ & $\Leftrightarrow$ & $\mathrm{Fe}^{2+}+2 \mathrm{H}_{2} \mathrm{O}-2 \mathrm{H}^{+}$ & $-13.905^{\mathrm{c}}$ \\
\hline
\end{tabular}

${ }^{\mathrm{a}}$ FromWATEQ4F database (2).

${ }^{b}$ Estimated from the aqueous concentrations. The activities of $\mathrm{Fe}^{2+}, \mathrm{OH}^{-}$, and $\mathrm{CO}_{3}{ }^{2-}$ were calculated using MINTEQA2 (1), and the ion activity products for 31 samples from columns B, C, and D were averaged to estimate the equilibrium constant. The average value was log IAP $=0.075( \pm 0.412)$. Equilibrium constants for aragonite and siderite, calculated in the same way for comparison, were within the range of values reported in the literature.

${ }^{\mathrm{c}}$ From EQ3/6 database (3). 
Table S5. Input parameters used in the simulations.

\begin{tabular}{|c|c|c|c|c|}
\hline \multirow[t]{3}{*}{ Parameter } & \multicolumn{4}{|l|}{ Column } \\
\hline & $\mathrm{A}$ & B & $\mathrm{C}$ & $\mathrm{D}$ \\
\hline & $\begin{array}{l}\text { (D.I. } \mathrm{H}_{2} \mathrm{O}+10 \\
\left.\text { mgL }^{-1} \mathrm{TCE}\right)\end{array}$ & $\begin{array}{l}\left(100 \mathrm{mgL}^{-1}\right. \\
\mathrm{CaCO}_{3}+10 \\
\left.\mathrm{mgL}^{-1} \mathrm{TCE}\right)\end{array}$ & $\begin{array}{l}\left(100 \mathrm{mgL}^{-1}\right. \\
\mathrm{CaCO}_{3}+10 \\
\mathrm{mgL}^{-1} \mathrm{TCE}, \\
\text { coarse iron) }\end{array}$ & $\begin{array}{l}\left(500 \mathrm{mgL}^{-1}\right. \\
\mathrm{CaCO}_{3}+10 \\
\left.\mathrm{mgL}^{-1} \mathrm{TCE}\right)\end{array}$ \\
\hline Column length (m) & 0.50 & 0.50 & 0.50 & 0.50 \\
\hline $\mathrm{Fe}^{0}$ volume fraction (-) & 0.47 & 0.45 & 0.45 & 0.49 \\
\hline Porosity (-) & 0.53 & 0.55 & 0.55 & 0.51 \\
\hline Hydraulic conductivity $\left(\mathrm{ms}^{-1}\right)$ & $1.00 \times 10^{-4}$ & $3.33 \times 10^{-5}$ & $1.00 \times 10^{-4}$ & $3.49 \times 10^{-5}$ \\
\hline Diffusion coefficient $\left(\mathrm{m}^{2} \mathrm{~s}^{-1}\right)$ & $1.5 \times 10^{-9}$ & $1.5 \times 10^{-9}$ & $1.5 \times 10^{-9}$ & $1.5 \times 10^{-9}$ \\
\hline Longitudinal dispersivity (m) & $9.9 \times 10^{-4}$ & $9.9 \times 10^{-4}$ & $9.9 \times 10^{-4}$ & $9.9 \times 10^{-4}$ \\
\hline Running time (days) & 601 & 462 & 704 & 410 \\
\hline Flow rate (Darcy flux) $\left(\mathrm{ms}^{-1}\right)$ & $1.38 \times 10^{-5}$ & $1.38 \times 10^{-5}$ & $1.38 \times 10^{-5}$ & $1.38 \times 10^{-5}$ \\
\hline $\mathrm{pH}$ & 7.32 & 7.44 & 7.44 & 6.66 \\
\hline $\mathrm{Ca}^{2+}\left(\mathrm{molL}^{-1}\right)$ & NA & $1.0 \times 10^{-3}$ & $1.0 \times 10^{-3}$ & $5.0 \times 10^{-3}$ \\
\hline $\mathrm{CO}_{3}^{2-}\left(\mathrm{molL}^{-1}\right)$ & NA & $2.49 \times 10^{-3}$ & $2.49 \times 10^{-3}$ & $1.57 \times 10^{-2}$ \\
\hline TCE $\left(\mathrm{molL}^{-1}\right)$ & $7.6 \times 10^{-5}$ & $7.6 \times 10^{-5}$ & $7.6 \times 10^{-5}$ & $7.6 \times 10^{-5}$ \\
\hline
\end{tabular}

NA: Not applicable. 
Comparison with the Results of the Column Experiments (Other than Column D). The simulations for the columns other than column D are presented in Figures S1-S3, with model parameters listed in Table 1.

For column A, it was assumed that $\mathrm{Fe}(\mathrm{OH})_{2}(\mathrm{am})$ was the only secondary mineral phase and the accumulation of this mineral was the cause of passivation, which was found to be less than in other columns. Generally, the simulated TCE profiles match the measured data quite well (Figure S1a). After Day 482, the measured TCE profiles are almost steady over the remainder of the experiment, suggesting that the column may have approached a steady-state condition. The simulation results, however, show slightly further migration because the model allows the reactivity loss to continue. There are significant discrepancies between the measured and simulated pH profiles (Figure S1b). The scattered plots for the measured $\mathrm{pH}$ values may be a consequence of measurement difficulties and are attributed to the low $\mathrm{pH}$ buffer capacity in this column. The accumulation of $\mathrm{Fe}(\mathrm{OH})_{2}(\mathrm{am})$ is not significant, but is more prominent in the region of greatest TCE degradation (Figure S1c) because of enhanced iron corrosion.

The migration of the TCE profiles in columns B and C (Figures S2a and S3a) is attributed to the precipitation of aragonite and $\mathrm{Fe}_{2}(\mathrm{OH})_{2} \mathrm{CO}_{3}(\mathrm{~s})$, with aragonite having the greater effect (Table 1). The simulated pH profiles do not precisely match the measured profiles (Figures S2b and S3b); however, the simulations successfully represent the trends and demonstrate how the geochemical conditions evolve over time. The simulated total carbonate volume fractions are generally consistent with the laboratorycalculated data (Figures S2c and S2d, and S3c and S3d), with the exception of the large increase of carbonates for column C at later times (Figure S3c). This increase is believed to be an experimental artifact. The slightly lower iron corrosion rate in column C than in column B (Table S3) results in less accumulation of carbonate minerals (Figures S2d and S3d). 

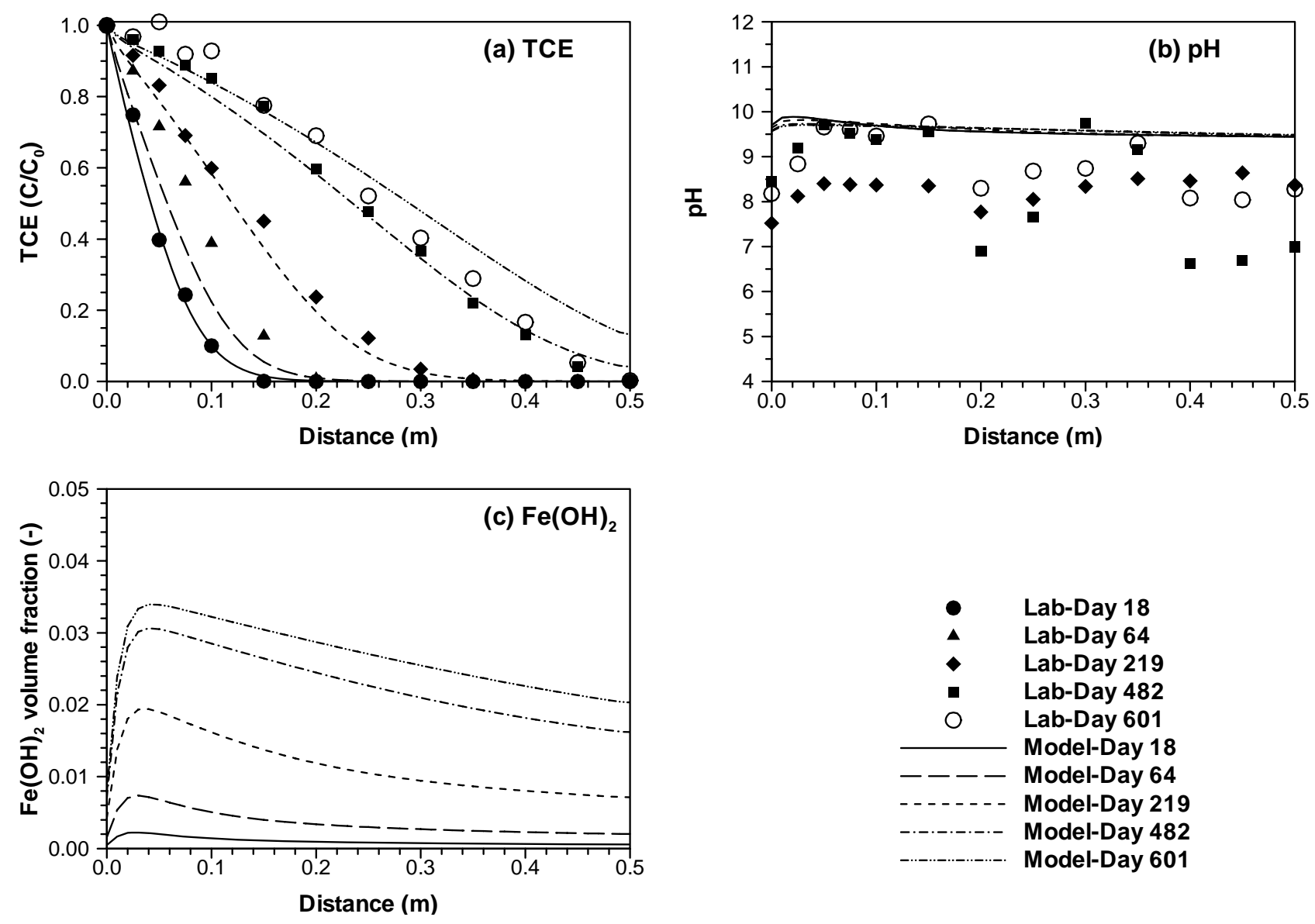

Figure S1. Measured and simulated profiles for column A (D.I. $\mathrm{H}_{2} \mathrm{O}+10 \mathrm{mgL}^{-1} \mathrm{TCE}$ ): (a) TCE, (b) pH, and (c) simulated $\mathrm{Fe}(\mathrm{OH})_{2}(\mathrm{am})$ volume fraction. 

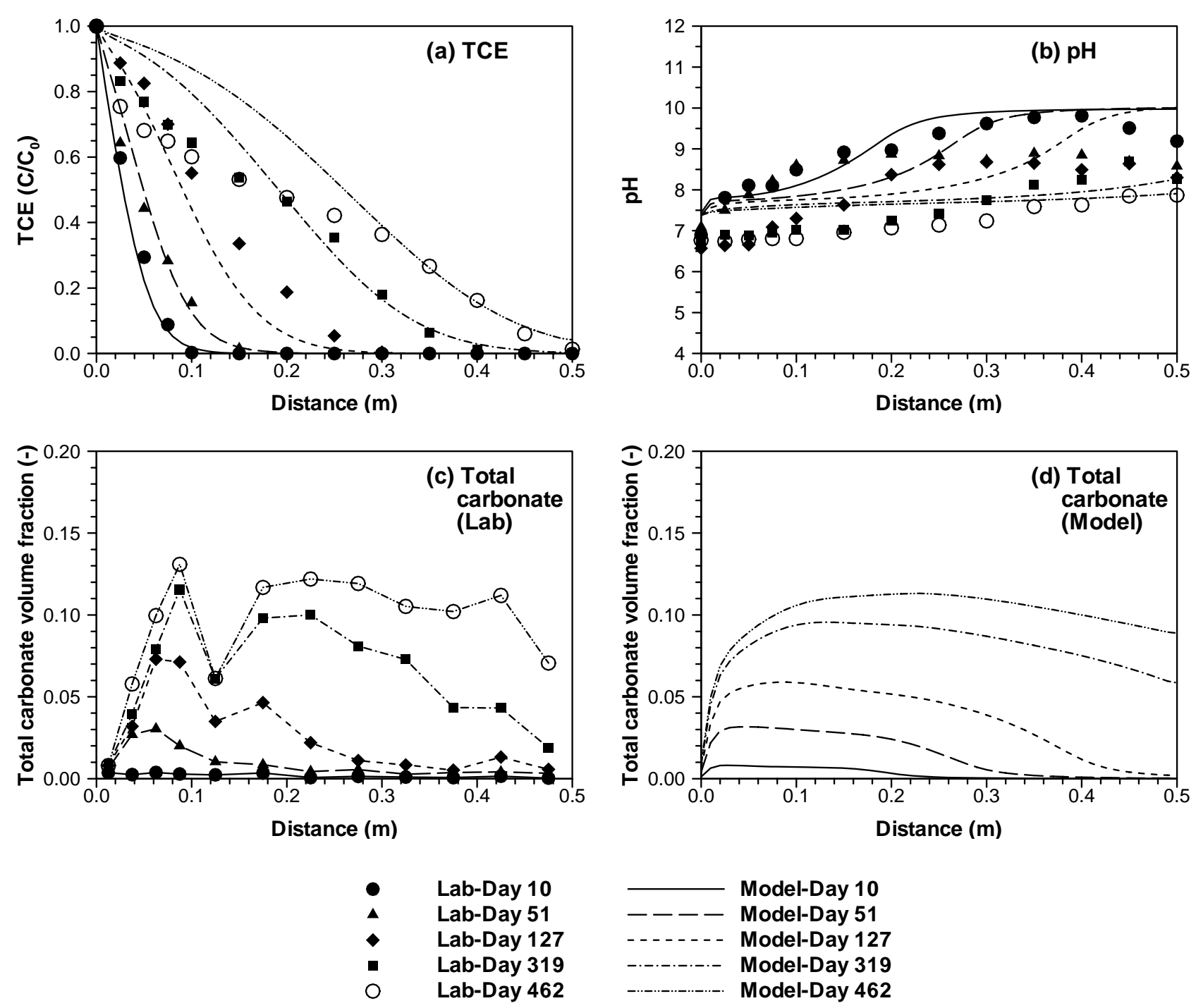

Figure S2. Measured and simulated profiles for column B $\left(100 \mathrm{mgL}^{-1} \mathrm{CaCO}_{3}+10 \mathrm{mgL}^{-1} \mathrm{TCE}\right)$ : (a) TCE, (b) $\mathrm{pH}$, (c) laboratory-calculated total carbonate volume fraction (lines are connections between two adjacent sampling ports), and (d) simulated total carbonate volume fraction. 

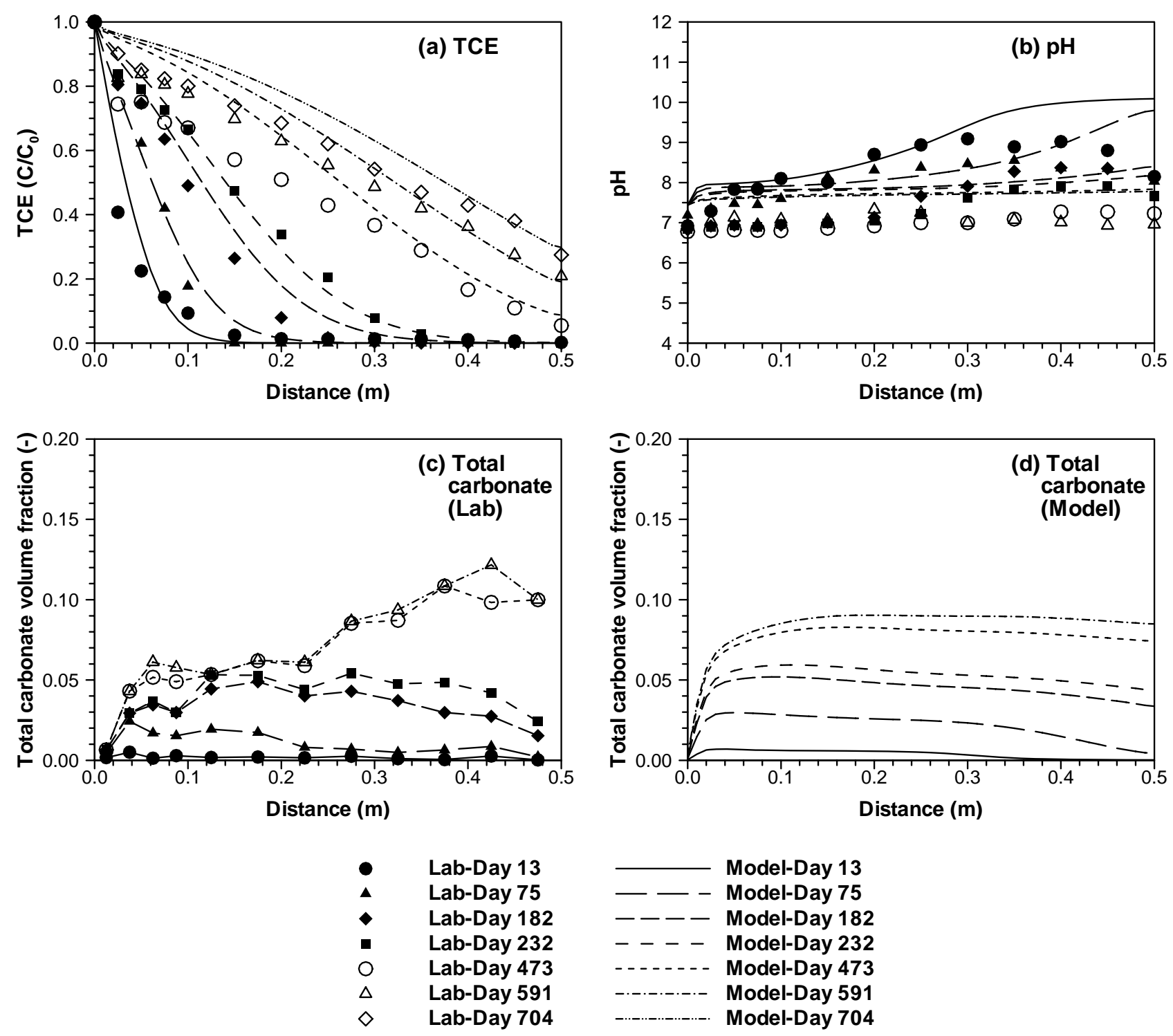

Figure S3. Measured and simulated profiles for column $\mathrm{C}\left(100 \mathrm{mgL}^{-1} \mathrm{CaCO}_{3}+10 \mathrm{mgL}^{-1} \mathrm{TCE}\right.$, coarse iron): (a) TCE, (b) $\mathrm{pH}$, (c) laboratory-calculated total carbonate volume fraction (lines are connections between two adjacent sampling ports), and (d) simulated total carbonate volume fraction. 

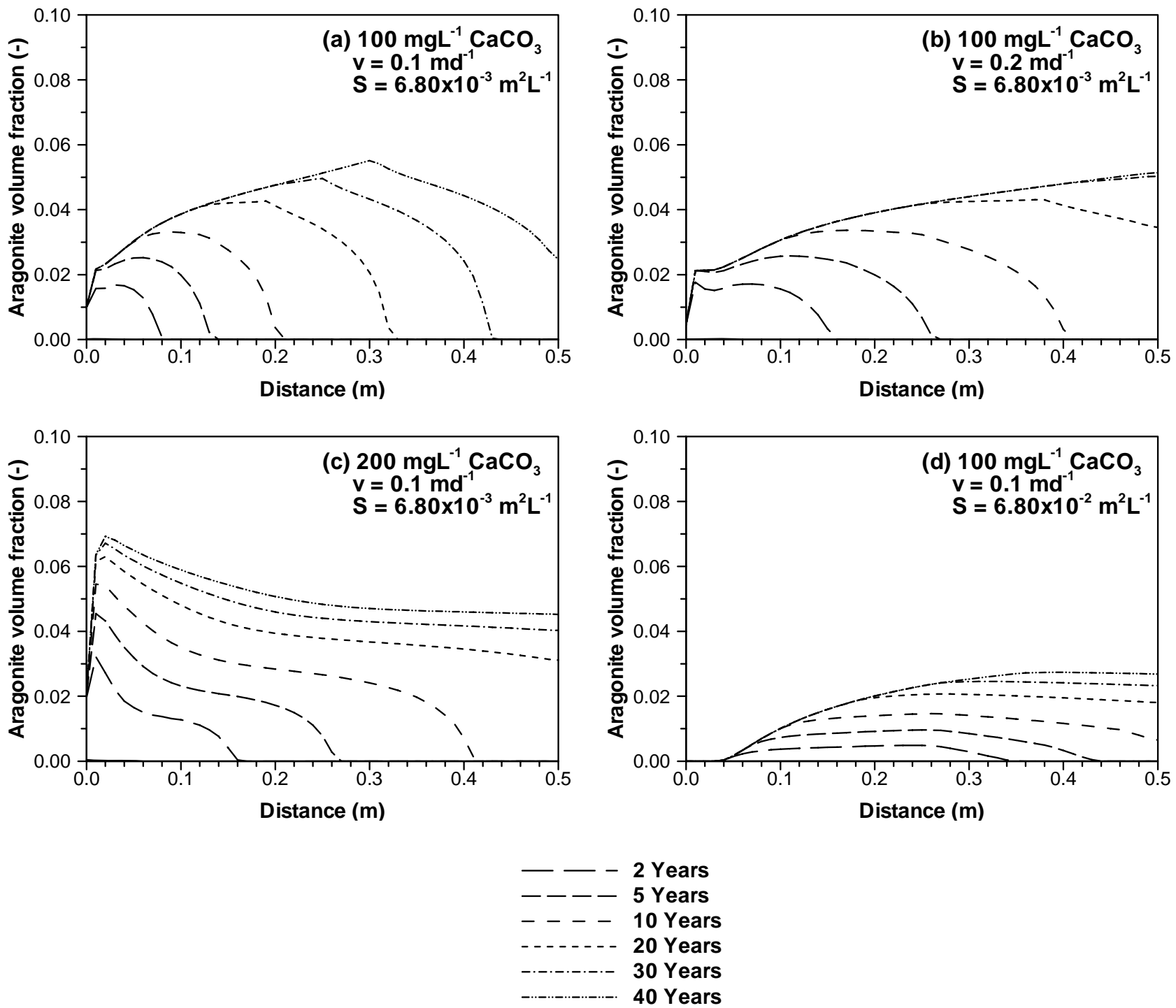

Figure S4. Predicted aragonite volume fraction (a) with a composition of $100 \mathrm{mgL}^{-1} \mathrm{CaCO}_{3}$ at a groundwater velocity of $0.1 \mathrm{md}^{-1}$, (b) with a composition of $100 \mathrm{mgL}^{-1} \mathrm{CaCO}_{3}$ at a groundwater velocity of $0.2 \mathrm{md}^{-1}$, (c) with a composition of $200 \mathrm{mgL}^{-1} \mathrm{CaCO}_{3}$ at a groundwater velocity of $0.1 \mathrm{md}^{-1}$, and (d) with a composition of $100 \mathrm{mgL}^{-1} \mathrm{CaCO}_{3}$ at a groundwater velocity of $0.1 \mathrm{md}^{-1}$, and with an one-orderof-magnitude smaller reactive surface area of iron. S represents the initial reactive surface area of the iron ( $\mathrm{m}^{2}$ iron $\mathrm{L}^{-1}$ bulk). 

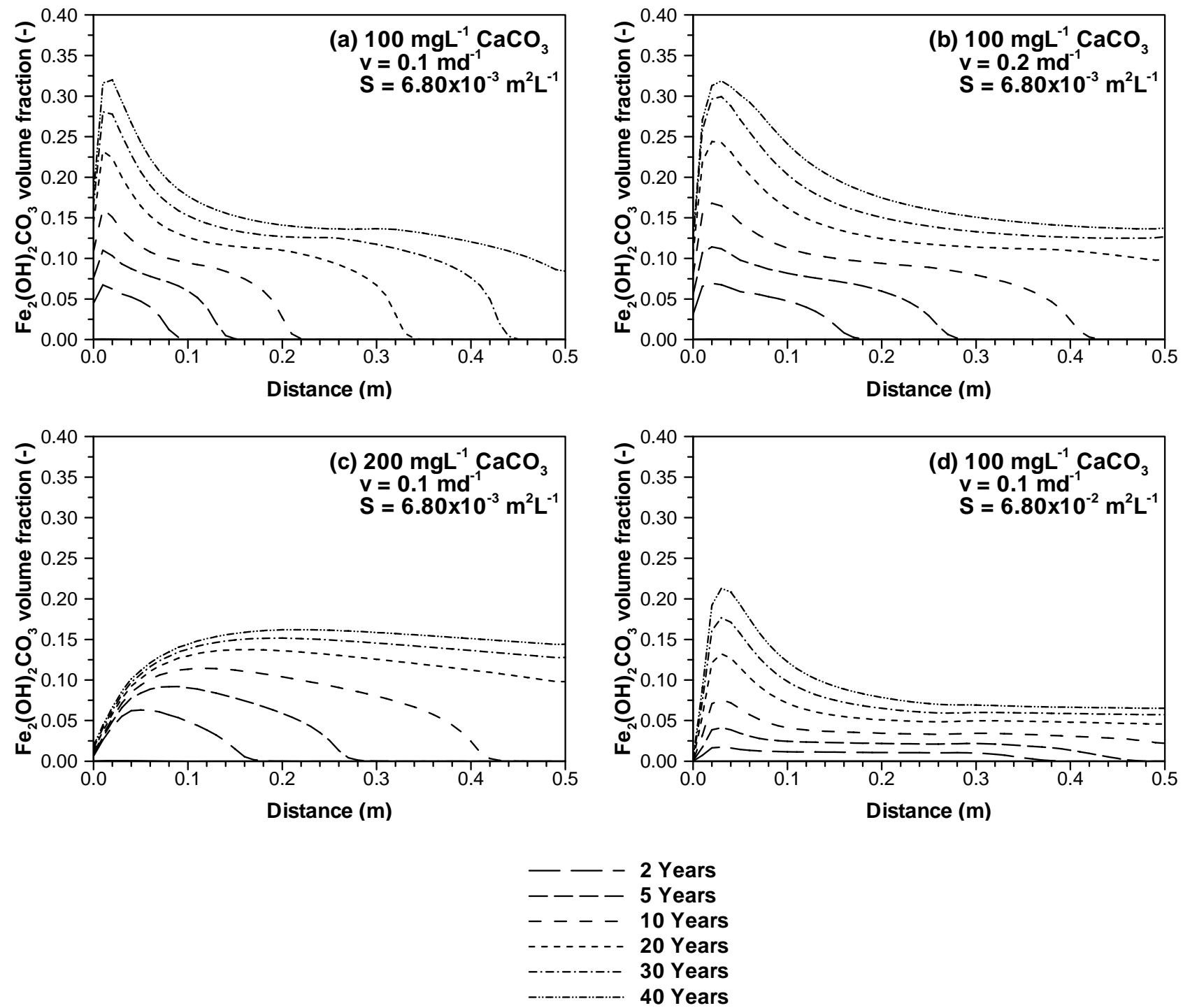

Figure S5. Predicted $\mathrm{Fe}_{2}(\mathrm{OH})_{2} \mathrm{CO}_{3}(\mathrm{~s})$ volume fraction (a) with a composition of $100 \mathrm{mgL}^{-1} \mathrm{CaCO}_{3}$ at a groundwater velocity of $0.1 \mathrm{md}^{-1}$, (b) with a composition of $100 \mathrm{mgL}^{-1} \mathrm{CaCO}_{3}$ at a groundwater velocity of $0.2 \mathrm{md}^{-1}$, (c) with a composition of $200 \mathrm{mgL}^{-1} \mathrm{CaCO}_{3}$ at a groundwater velocity of $0.1 \mathrm{md}^{-1}$, and (d) with a composition of $100 \mathrm{mgL}^{-1} \mathrm{CaCO}_{3}$ at a groundwater velocity of $0.1 \mathrm{md}^{-1}$, and with an one-orderof-magnitude smaller reactive surface area of iron. S represents the initial reactive surface area of the iron ( $\mathrm{m}^{2}$ iron $\mathrm{L}^{-1}$ bulk). 


\section{Literature Cited}

(1) Allison, J. D.; Brown, D. S.; Novo-Gradac, K. J. MINTEQA2/PRODEFA2, A Geochemical Assessment Model for Environmental Systems: Version 3.0 User's Manual; EPA/600/3-91/021; U.S. EPA, Environmental Research Laboratory: Boulder, CO, 1991.

(2) Ball, J. W.; Nordstrom, D. K. User's Manual for WATEQ4F, with Revised Thermodynamic Database and Test Cases for Calculating Speciation of Major, Trace and Redox Elements in Natural Waters; U.S. Geological Survey Open-File Report 91-183; USGS: Reston, VA, 1991.

(3) Wolery, T. J.; Daveler, S. A. EQ6, A Computer Program for Reaction Path Modeling of Aqueous Geochemical Systems: Theoretical Manual, User's Guide, and Related Documentation (Version 7.0); E1.28: UCRL-MA-110662Pt4; Lawrence Livermore National Laboratory: Livermore, CA, 1992. 